\title{
LITERATURA, HISTÓRIA E COMUNICAÇÃO DE MASSAS: O ENTRELUGAR DOS DISCURSOS.
}

\section{LITERATURE, HISTORY AND COMMUNICATION OF MASSES: THE ENTRELUGAR OF THE SPEECHES.}

\author{
Prof. Dr. Goiamérico Felício Carneiro dos Santos*
}

RESUMO: A linguagem literária e a linguagem da comunicação de massa têm suas configurações específicas e são reguladas por leis próprias, na medida em que têm objetivos diferentes. Enquanto aquela faz o registro do poético e que por isso transcende a objetividade, esta procura nunca sair dos domínios da pura objetividade da língua buscando uma comunicação imediata, com efeitos imediatos, que não deixa rastro na construção do imaginário. Por outro lado, segundo as perspectivas da Nova Historiografia, os discursos são repletos de lacunas, defrontando o historiador com a impossibilidade de arrogar para si a tarefa de recuperar tudo o que aconteceu. Assim, as fronteiras dos discursos literários, históricos e comunicacionais, cada vez mais, vêm sendo borradas, destituídas das linhas demarcatórias entre o fato e a ficção.

PALAVRAS-CHAVE: Literatura, História, Comunicação, Discursos.

ABSTRACT: Both the literary and the mass communication languages have their specific configurations and are ruled by their own laws since they have different purposes. As the first one registers the poetic and for that transcends objectivity, the second one tries never to leave the domain of pure objectivity seeking immediate communication, with immediate effects, which are never rooted in the construction of the imaginary. On the other hand, under the New Historiography perspective, discourses are plenty of omissions which confront the historian with the impossibility of his idea of recovering or retelling everything that took place in time. The frontiers between the literary, the historical, and the communicational discourses are more and more blurred every day, deprived as they are of the delimiting lines between fact and fiction.

KEY WORDS: Literature, History, Communication, Discourses.

\footnotetext{
* Poeta, professor e pesquisador do Mestrado em Literatura: crítica literária, do Departamento de Letras da Universidade Católica de Goiás - UCG; Coordenador do Mestrado em Comunicação da Universidade Federal de Goiás da Facomb - Faculdade de Comunicação e Biblioteconomia - UFG.
} 



\section{LITERATURA, HISTÓRIA E COMUNICAÇÃO DE MASSAS: O ENTRELUGAR DOS DISCURSOS.}

Afinal, o que há de comum entre um texto dito de massa e um texto que se faz para as elites? No mínimo que são dois tipos de discurso que atravessam o nosso ser. Dois tipos de discursos, cada qual com suas peculiaridades, cada qual ao seu modo, um mais, outro muito menos, que tornam significativas as nossas existências. Ousaríamos ainda acrescentar que vivemos sob a égide desses dois tipos de discursos no cotidiano de nossas vidas. Enquanto os discursos de massa vêm fazer o apelo para o imediatismo do consumo, o discurso literário nos conclama para mergulharmos nos perigosos desvãos da linguagem que, ao modo de uma esfinge, sempre nos ameaça devorar.

\section{Para onde vai a literatura?}

Estas considerações nos reportam ao diálogo travado por Roland Barthes e Maurice Nadeau em torno da questão "Para onde vai a literatura?”, A essa provocação de Nadeau, Roland Barthes, sem hesitação, responde: "Para a sua perda".

Mas, como Barthes mesmo aduz, essa resposta abortaria a possibilidade de continuidade do debate. Ensejando continuar a conversa, Maurice Nadeu traz à tona a citação de Blanchot lembrada por Barthes: "Para onde vai a literatura? Vai direito a si mesma. Direito à sua essência, que é a sua de-

${ }^{1}$ O diálogo do qual nos valemos, "Para/ou onde vai a literatura?", travado entre Roland Barthes e Maurice Nadeau, está em BARTHES, Roland [et. Alii], 1975, p. 9. 
saparição" . Para Nadeau, Blanchot tem a palavra "Desaparição", ao menos nesse momento, um sentido um tanto metafísico. Afinal, concretamente falando, a pergunta é: “'Em que situação se encontra actualmente a literatura?' Ora, nem tu nem eu somos profetas e, quanto a mim, não sei de todo para onde ela vai. A pergunta não seria mais vasta? Não equivalerá a esta: 'Que é a literatura '?"3.

Ao que Barthes responde com uma provocação maior ainda: "Para onde deve ir a literatura?"4. É Barthes mesmo quem objeta ser necessário explorar alguns aspectos da literatura, já que o conceito literatura tem se mostrado, ao longo dos anos, vago e impreciso. "Há que não esquecer que, por exemplo, que a própria palavra 'literatura' é bastante recente: no plano terminológico, existe apenas desde o final do século XVIII. Anteriormente, falava-se de 'letras', de 'belas letras', e por isso era outra coisa"'.

Vale pensar também com Barthes que a literatura deve ser situada num quadro social. Afinal, ela é praticada dentro de uma sociedade. Desse modo, a literatura não vem a ser um objeto atemporal com valor intemporal. Literatura é, antes de mais nada, uma série de textos construídos de acordo com um certo tipo de pensamento praticado numa certa época por certos grupos sociais, ou seja, por famílias literárias.

Assim, vemos que a literatura é apenas um tipo de discurso. Ela é apenas uma dentre tantas linguagens que se diferenciam de acordo com o fim a que se prestam. Só que a linguagem literária tem uma peculiaridade tal que se distingue de todas as outras ${ }^{6}$. Essas ponderações de Barthes significam um decisivo passo rumo ao norteamento do que seja a escrita literária. Mas será que ela ainda responde aos nossos anseios quanto à questão da linguagem literária? Afinal, já não podemos perder de perspectiva a posição do leitor, ou dos diferenciados leitores que se apresentam ao longo dos desdobramentos socioculturais que ensejam um certo fazer literário. Senão vejamos, conforme bem nos asseverou Barthes, que o conceito do que seja literário tem sido vago e cambiante.

Segundo o jornal Folha de São Paulo, de 12 de maio de 1996, a americana Janet Cooke, que em 1981 recebeu prêmio por história inventada sobre

\footnotetext{
${ }^{2}$ Idem, ibidem.

3 dem, p. 10.

${ }^{4}$ Idem, ibidem.

${ }^{5}$ Idem, ibidem.

${ }^{6}$ Idem, p. 11.
} 
garoto drogado que hoje é balconista. Após 15 anos de silêncio, a responsável pelo maior escândalo ético na história do jornalismo norte-americano, Janet Cooke, resolveu voltar ao cenário público.

Em 1981, a então promissora repórter de 26 anos ganhou o prêmio mais cobiçado da profissão, o Pulitzer, por comovente reportagem sobre um garoto de oito anos, chamado Jimmy, viciado em heroína.

"Só que o menino nunca existiu, a não ser na imaginação da autora da reportagem, como descobriram seus superiores no The Washington Post, após um interrogatório de 11 horas 'O que eu fiz foi errado. Eu lamento. Eu fui a culpada e tenho vergonha do que fiz. Mas acho que no meu caso o castigo foi maior do que o crime"'.

Essa breve notícia de jornal nos remete a um dos pontos mais, digamos, interessantes da Nova História, pois coloca em evidência as novas perspectivas dessa nova maneira de historicizar os acontecimentos do mundo. Qual seja, uma nova abordagem da história que passa da história-narrativa à história-problema. Assim, no dizer de Furet temos que: "A história é filha da narrativa. Não se define por um objecto de estudo, mas por um tipo de discurso. Dizer que estuda o tempo não tem de facto outro sentido que dizer que dispõe todos os objectos que estuda no tempo: fazer uma história é contar uma história"7.

Ou seja, o historiador agora passa a definir o seu objeto de estudo, que virá atender às suas curiosidades e aos seus interesses, ele tende a 'inventar' as suas fontes através da maneira pela qual processa a seleção dos informantes que trazem consigo uma visão subjetiva dos fatos e também uma certa carga de afetividade que cada espectador da história inapelavelmente carrega consigo. Desta maneira, não é sem espanto que nos ocorre a pergunta: que crime cometeu Janet Cooke?

Melhor seria encararmos Janet Cooke sob novas premissas. Qual seja, a de que sendo a História Nova uma enciclopédia, tudo nela cabe, inclusive a ficção criada pela então jornalista, tão presente nas histórias já escritas e tão ignoradas por nós ${ }^{8}$. Tudo cabe nessa Nova História, inclusive o relato dessa infeliz jornalista, que bem poderia ser aceita como uma nova historiadora.

\footnotetext{
${ }^{7}$ FURET, François. "Da história-narrativa à narrativa-problema”, In A oficina da história. Lisboa: Gradiva, sd.

${ }^{8}$ LE GOFF, Jacques. 1990, p. 39.
} 
Exagero incomparavelmente maior cometeu Marco Polo. Todos nós crescemos com a nítida certeza de que o veneziano foi à China, vivenciando um mundo novo e estranho para contá-lo aos ocidentais. Os livros de história nos relatam a aventura de Marco Polo como um dos grandes feitos do milênio. Um feito tão grande que é comparável apenas à viagem de Cristovão Colombo à América e à chegada do homem à lua. Tudo isso não passa da mais pura fantasia, de acordo com as palavras da chefe do Departamento da China da British Library, Frances Wood.

Em seu livro Did Marco Polo Go to China? (Marco Polo foi à China?) segundo resenha de "Veja" à obra da pesquisadora inglesa (edição 1439, de 10/04/96), Marco Polo não passava de um grande falastrão e de um péssimo repórter.

A obra de Wood questiona: se realmente Marco Polo foi à China, ele inventou coisas que não viu, exagerou as que "viu", e não relatou o que realmente viu. Basta lembrar que, quando Marco Polo alega ter ido à China, a famosa Muralha já estava lá, firme, forte e, ostensivamente, visível. Sabemos, hoje, que a Muralha da China é um dos poucos pontos da terra visíveis da lua. Contudo, ao que parece, o veneziano não a viu. Como deixar de relatar uma obra tão descomunal? Como também deixar de relatar os ideogramas da língua chinesa? Marco Polo, tão rico em imaginação e tão pobre em verdade, ainda preferiu relatar absurdos como ao deparar com homens sem cabeça, mas ignorou as mulheres com pés deformados.

Casos como os de Marco Polo colocam a Nova História numa situação bastante delicada. Afinal, o flerte da história com as outras ciências humanas, esse namoro firme com a ficção, se constituirá em casamento com final feliz ad infinitum. Ou mais: quais serão os limites da história e da ficção? É bem verdade que os novos historiadores constituem-se em verdadeiros estilistas da língua. O tipo de discurso que produzem os novos historiadores é que tornará crível o que relatam. Segundo Jacques Le Goff:

"Uma das características e um das grandes realizações da História Nova, e que coloca doutro modo o problema de sua credibilidade, consiste numa enorme dilatação do campo do documento. Isto contempla, por um lado, o recuo do documento escrito, a busca do documento arqueológico figurativo, do documento oral, que é interrogar os silêncios da história, a entrada em cena do documento imaginário"'.

${ }^{9}$ LE GOFF, Jacques, A Nova História, Lisboa: Edições 70, s/d. p. 34. 
Assim, o texto literário (fictício) terá tanta "verdade" quanto a produção especializada. Se isso acarreta problemas tanto para a história quanto para a ficção, "é importante se distinguir o documento "falso" do documento "verdadeiro" ${ }^{10}$. Emmanuelle Roy Ladurie enfatiza ainda:

"Na medida em que literatos como Roland Barthes abandonam a idéia do real e da realismo, o documento literário recai , sob este ponto de vista, nas mãos dos historiadores. Pode igualmente verificar-se o emergir de uma nova literatura: Pierre Rivière será talvez considerado um dia como um grande escritor, ainda que um tanto ambíguo, tal como Corneille ou Malherbe"11.

Assim, se existe uma nova história, a literatura escrita inconscientemente por não literatos do escopo de Rivière, ou mesmo pelo tipógrafo Nicolas Contat este autor de O grande massacre de gatos, se configuraria como um novo gênero literário? Afinal, essa literatura gerada tão somente pelo inconsciente, deu conta com mais propriedade do imaginário e dos anseios dos atores de seus tempos que a chamada "literatura oficial".

\section{O texto literário: um modelo complexo de comunicação?}

“Eu não leio textos literários, eu leio textos literariamente.” (G. F.)

Segundo as perspectivas da Nova Historiografia, tudo o que ocorreu deve ser objeto de interesse da historia. E o leitor dotado de espírito crítico sabe que a história nada mais é que um discurso. Os discursos, como se sabe, são repletos de lacunas. Sabe-se também da impossibilidade com que se defronta a historiador que arrogar para si a tarefa de recuperar tudo o que aconteceu. $\mathrm{O}$ problema está nas fontes, que nunca dão conta de tudo o que sucedeu. $\mathrm{E}$ ainda assim, o historiador não pode dizer mais do que as fontes. E ainda de onde são essas fontes? Qual é o lugar que ocupa o historiador, qual é o seu compromisso? "Todo livro de história é um tecido de incoerências"12.

É com a Nova História, a que aspira a totalidade da história, que compreendemos: os fatos não têm grandeza absoluta, não são mais importantes

\footnotetext{
${ }^{10}$ Idem, ibidem, p. 35.

${ }^{11}$ Idem, ibidem.

${ }^{12}$ VEYNE, Paul. “Tudo é histórico, portanto a história não existe”, In: SILVA, Maria B.N. da., 1976, p.46.
} 
que os outros; a importância que eles têm depende dos critérios escolhidos pelo historiador.

Assim, impossível será determinar o que é histórico é o que não é digno de tal registro. Será preciso, então, admitir que tudo é histórico. Tal extremismo pressupõe a subjetividade da história. E que: "O mérito do historicismo é talvez o de ter trazido à luz as dificuldades da idéia de História e os limites da objetividade histórica; é ainda mais simples não começar por colocar a idéia de História e admitir que o sublunar seja o reino do provável"13.

E se a subjetividade da História consiste no fato de não podermos dar conta da descrição do futuro, nos debruçamos ante o passado. Escolher qualquer assunto, já que não podemos nos ocupar de todos eles, reforça a concepção da subjetividade da história.

Se a história é tida como produção subjetiva, não estará ela se constituindo em um problema para a literatura? Não deixa de provocar um certo mal-estar e até mesmo um transtorno a questão da transdisciplinaridade hoje tão em voga. Principalmente, quando se relaciona a atividade científica e o fazer ficcional.

"Até hoje, a velha dicotomia platônica, acredita que o poético embeleza o que desconhece, enquanto a ciência, depois de destronar a filosofia, tira a verdade do fundo do poço. Mas, se já não há verdade a ser inteira e plenamente resgatada, se a ciência passa a se conceber como as propriedades de um objeto e uma linguagem - que supõe a tomada de um lugar - que formula e equaciona certos aspectos seus, que validade então ainda passa a ter a velha dicotomia e a conseqüente hierarquia que ela implicava?"14.

Se o poético já não é reserva de domínio dos poetas, dos escritores, críticos, estetas e historiadores da literatura; se todas as fronteiras foram abolidas, tudo agora é gênero literário? A história é agora um gênero literário? Pensando com Paul Veyne. Levar às últimas conseqüências a idéia de que tudo é histórico, é incorrer o risco de tornar inofensivo o historicismo.

O mesmo perigo não corre o discurso literário? Ou seja: levar também às últimas conseqüências a concepção de que agora tudo é literário, pode

\footnotetext{
${ }^{13}$ Idem, ibidem, p. 54/5.

${ }^{14}$ LIMA, Luís Costa. 1984, p. 190.
} 
também levar esse tipo peculiar de discurso a um estado inofensivo. Se já não importa mais a realidade, que está morta, o deus agora é a escrita. $\mathrm{E}$ a diferença estaria tão somente entre duas plêiades: a dos escritores e a dos escrivinhadores.

Os formalistas russos, no século XX, ainda tentaram articular uma barreira, buscando a manutenção da reserva de domínio do específico literário. A essa propriedade os formalistas denominaram literariedade. Afinal, esse específico literário, essa literariedade, pode ser discernida tão facilmente? Quem procura definições últimas e verdadeiras ainda não encontrou descanso. Não é sem razão que essa dúvida ainda persiste provocando, e muito, os estudiosos da questão. Há quem sustente uma resposta positiva. Pelo fato de que a "literariedade" seria a propriedade universal específica que distinguiria a particularidade de uma obra como literária. E a "literariedade" não poderia passar de mais um rótulo? Quem determinaria o que é "literariedade"? Essa visão de "literariedade" seria imutável ad infinitum? Sabemos que "Os modos de produção de sentidos do presente interrogam os do passado, a formação social do historiador entra em contato com outra formação, às vezes profundamente diferente da dele"15. Isso poderia, então significar um caos na delimitação das fronteiras? Talvez sim, caso atentássemos para o fato de que:

"Na verdade, em cada período histórico podemos observar uma certa ordem, a partir da qual se estabelece, com maior ou menor rigidez, as fronteiras do literário (...). Cada época tem seu quadro de referência para identificar a literatura, tem suas normas estéticas, a partir da qual efetua julgamentos"16.

Assim, uma obra poderá ser considerada literária ou não; ou possuidora de mais ou menos "literariedade", de acordo com os julgamentos de valor a que pertence. Ou seja: o contexto é quem determina o literário. A própria mudança de critérios, de julgamentos de valor, se constituirá em objeto de estudo para o historiador. Esse historiador que é, sobretudo, um leitor, faz parte de um sistema; ele também possui sua família, não a edípica, mas a sua família interpretativa, os seus pares, com quem e para quem escreve. É com a visão do seu círculo interpretativo que esse historiador escreverá a

\footnotetext{
${ }^{15}$ JOBIM, José Luís, 1992, p. 129.

${ }^{16}$ Idem, ibidem.
} 
sua história. As obras por ele consideradas literárias estarão atendendo às suas expectativas, às expectativas de seus pares. Pois se é verdade que um homem não vive sozinho, também é verdade que nenhum homem escreve sozinho: "A maneira pela qual uma obra literária, no momento histórico de sua aparição, atende, supera, decepciona ou contraria as expectativas de seu público inicial oferece-nos claramente um critério para a determinação de seu valor estético" ${ }^{17}$.

Essa mudança de horizonte, a análise de seu efeito, é que consistirá a história da literatura escrita pelo leitor. Entramos assim, na seara do modelo complexo de comunicação. A interação entre o escritor e o leitor ocorrerá no momento em que o emissor e o receptor entram em sintonia; no momento em que eles se encontrem na mesma arena. Dessa maneira:

"A nova historiografia literária não demanda hipóteses gerais permanentes, mas formulações transitórias de validade limitada, que, mesmo assim, correspondem a consensos intersubjetivos negociáveis por comunidades científicas quanto a estratégias eficientes na solução de questões sentidas como problemáticas em função de certos interesses e paixões"18.

Não será por mero acaso que a partir do momento em que esse espaço está destituído de fronteiras; que há uma simultaneidade de consciências de um lugar historicamente ocupado institucionalmente; e de que o objeto de seu discurso tem um caráter construtivo, a tarefa do historiador torne-se ainda mais instigante. Uma tarefa sobremaneira criativa e estimulante, mas também revestida de uma dificuldade imensa.

Essa nova tarefa do historiador coloca em discussão postulados antigos e cheios de certezas. Nada mais que justo. Afinal, se a literatura tem esse caráter altamente dinâmico, a apreensão do fenômeno literário também, e fatalmente, teria que se dinamizar. Se há uma nova história, uma nova apreensão e um novo registro do que se pensa saber, há também uma nova historiografia literária a ser repensada.

"Para S. J. Schmidt, a mudança evidencia uma passagem mais abrangente do texto para o sistema literatura, ou seja, a substituição de concepções formalistas,

\footnotetext{
${ }^{17}$ JAUSS, Hans Robert. 1994, p. 31.

${ }^{18}$ OLINTO, Heidrun Krieger, 1996, p. 17.
} 
em que a identidade do estatuto literário se confunde com propriedades textuais, para uma compreensão pragmática do fenômeno literário como sistema social específico caracterizado por complexas relações comunicacionais" ${ }^{\prime 1}$.

Mas este novo modelo de construção do literário acabou provocando abalos nas concepções teóricas do discurso da comunicação. No modelo explicativo de Roman Jakobson, pó exemplo, um emissor envia uma mensagem codificada que referencia um contexto determinado para que um receptor, até mesmo o que se encontre totalmente fora desse contexto, a decodifique. Nesse modelo, as mensagens estão determinadas e os interlocutores estão fixos, conservando as suas próprias identidades. Não estaria aqui ainda vigorando a concepção de um mundo platonicamente fixo, imobilizado; um mundo de verdades estabelecidas a serem resgatadas?

E a primeira fase da teoria formalista, que tinha como finalidade colocar a literatura com o mesmo estatuto da ciência, distanciando-a das demais disciplinas humanas, esta não impediu um movimento inverso. Um movimento consubstanciando na teoria proposta por Bakhtin, onde o conceito de linguagem fundamentado no discurso verbal. O fenômeno social está intrinsecamente entrelaçado ao discurso:

"O caráter pluriforme do discurso é explicado [...] a partir da natureza dialógica da linguagem e da coexistência de enunciados sociais heterogêneos, abrindo, desse modo, um espaço que foi preenchido, igualmente, por outros teóricos do discurso da alteridade, da estética da recepção, e, especialmente, por uma teoria da ação comunicativa"20.

Estamos agora frente a novas e provocativas concepções acerca da apreensão do significado no texto literário. Para Stanley Fish, por exemplo, "Os significados não são propriedades nem de textos fixos e estáveis, nem de leitores livres e independentes, mas de comunidades interpretativas que são responsáveis tanto pela forma das atividades do leitor quanto pelos textos que estas atividades produzem"21.

\footnotetext{
${ }^{19}$ Idem, ibidem, p. $18,19$.

${ }^{20}$ Idem, ibidem, p. 20.

${ }^{21}$ FISH, Stanley, 1993, p. 156.
} 
Essa concepção nos faz lembrar uma resposta do contista argentino Horácio Quiroga quanto à definição do conto: "conto é tudo aquilo que você chamar de conto". Essa resposta, que desavisados atribuem ao nosso Mário de Andrade, aparentemente ríspida e com um certo tom de desfastio, vem se coadunar perfeitamente com as atuais questões interpretativas. Antigas "verdades" estão agora soterradas. Agora, para Iser, por exemplo, a leitura é um gesto analítico, um processo metodológico. E o sujeito passivo cedeu lugar a um sujeito que é construtor de sentidos, construtor de obras.

Finalmente ocorreu a fusão da dicotomia: autor-obra-leitor. A literatura agora é percebida como uma experiência estética de um leitor situado socialmente. Assim como propuseram os românticos, o valor estético é agora vinculado à categoria da inovação. Só que, para ir mais além, temos a consciência de que quanto se frustrar o horizonte de expectativas do leitor, mais valor estético conterá o texto. Os significados dos textos se deslocam juntamente com o deslocar dos horizontes de expectativas.

Mas a pergunta acerca do sentido da literatura, da permanência da literatura como fator de condição de sobrevivência de um certo tipo de pessoas, continua a martelar as mais privilegiadas mentes. A pergunta "por que a literatura" se renova parecendo padecer de uma eterna contemporaneidade. Esse indagar acaba sendo tomado por um desconforto agora já impossível de ser dissipado, muito menos de resguardado nas inquietações interiores ou de foro mais íntimo. Estamos agora no limiar do século XX. Um tempo em que a literatura se tornou autoconsciente, um tempo em que se tem consciência da precariedade da literatura como resposta para as fundas questões que, cada vez mais agudamente passaram a martelar as consciências problematizadoras.

"À medida que nos aproximamos do século XX, o homem parece contentar-se menos com a pura realização da sua obra. Antes, ou simultaneamente ele se indaga sobre sua razão. Não é que a inquietude fosse desconhecida antes. É que no passado o criador não problematizava o seu ofício; tinha-o por assente"22.

Até o advento do século XX, que trouxe em seu bojo tantos tormentos, o problema do artista era unicamente o da feitura da sua obra. O seu próprio ofício, a pertinácia de se criar uma obra artística não estava em questão.

${ }^{22}$ LIMA, Luiz Costa, 1969, p. 9. 
Como exemplo, centremos nossas atenções agora sobre a presença do grandioso vulto do bardo que deu sentido e hombridade à nossa língua portuguesa, através da qual foram expressas belíssimas páginas da literatura que deu notícia das grandes descobertas do povo português. Qual seria a grande inquietação de Camões naqueles tempos de grandes aventuras, de grandes descobertas? Certamente que o bardo português escreveu movido por uma inquietação quanto aos rumos da história de Portugal tão sedento de um passado glorioso para assim ter coragem e audácia para se aventurar na corrida pela sobrevivência enquanto nação:

"Camões não se indagava nem se o desconcerto do mundo podia ser dito entre rimas e versos, nem se ele cabia nas mesmas redondilhas em que cantara desenganos de amor, ninfas e idílios pastorais. O que vem a dizer: ausente esta problematização total da arte, o artista nem se indagava sobre a procedência de seus meios, nem se perguntava sobre sua função. Ambas eram dadas por assentes”23.

Não se quer com isso dizer que a ausência total de problematização por parte do artista do nosso passado. Tampouco se infere que o artista de então estava em conforto maior que o de hoje, muito menos que fossem aqueles artistas dotados de mais ingenuidade e confiança e até mesmo de mais auto-estima que os artistas desse século. O que se propõe é que todas os tormentos que viveram os artistas daqueles idos tempos não fizeram com que eles não se perguntassem sobre a necessidade ou não de sua arte. Eles cantavam, enformavam as suas artes porque assim tinha que ser. Talvez porque a musas os incitavam à tarefa. Eles viviam, quando muito, os seus dilemas face aos percalços que tornam difícil o caminhar dos homens ao longo da construção de suas histórias. Só que os seus dilemas não se transformavam em crise.

Vivemos hoje em perpétua crise existencial e também uma permanente crise no que se refere à criação artística. Se antes, tão somente face às crises existenciais e sociais o homem se via compelido a criar, a fazer arte, hoje o artista se vê ainda sob o peso da crise da criação humana:

"No caso da arte, isto leva a uma dupla problematicidade: é uma crise existencial para a obra e também para o seu feito. Este se pergunta sobre o sentido do

\footnotetext{
${ }^{23}$ Idem: 9, 10.
} 
seu esforço e ao se perguntar assim, ele se pergunta sobre o sentidos dos limites configurados para o seu fazer, sobre o sentido da tradição, tanto técnica, quanto espiritual" 24 .

\section{Literatura e comunicação de massas: derrubando fronteiras}

Atentemos para o fato de que o que está em perspectiva é a questão que envolve a literatura e a comunicação de massa. Por isso, todas as considerações acima expostas podem levar à seguinte pergunta: literatura não é um produto sofisticado demais para um povo tão chegado às letras como o brasileiro? Ou mais: preocupar-se com a pertinência da literatura entre nós quando temos problemas emergenciais a serem resolvidos não é coisa de desocupados? Afinal, vivemos em tempos de crise, em aguda crise de uma nação subdesenvolvida. Tratemos do que é mais pertinente, tratemos dos nossos males sociais que tanto afetam a conjuntura nacional.

Bertold Brecht já deixou claro que se a arte e a literatura têm função catártica para o público, essa catarse se efetua também nas instâncias do autor. Somos hoje conscientes das causas dos nossos males sociais. Dessa feita, não podemos nos contentar com o papel terapêutico das artes. Não estamos aqui propondo a anulação desse papel terapêutico da catarse. Admitamos ainda que as artes também desempenham o papel de propiciar lazer no cotidiano grande massa. Apenas se questiona se considerando esses fatores como preponderantes não estaremos reduzindo por demais a presença da arte e da literatura na vida dos homens. Principalmente no que concerne à expressão artística através da palavra, considerá-la enquanto elemento propiciador de catarse significaria colocá-la na mesma configuração de uma droga, de um ópio do povo, como dissera Karl Marx.

Nesse aspecto, a literatura estaria ainda mais em profunda desvantagem. Isso porque a literatura tem hoje um concorrente poderosíssimo que atende pelo nome de "cultura enlatada". Essa, sim, tem o poder de provocar a catarse e de levar o lazer à multidão enfastiada. A expressão artística, quanto mais elaborada ela for, mais ela estará em desvantagem face às alternativas oferecidas pela "indústria cultural". A literatura, por ser fruto de penosa elaboração formal, não tem como concorrer com as inúmeras atrações que atendem ao gosto das massas que preferem o mais facilmente digerível:

\footnotetext{
${ }^{24}$ Idem: 11.
} 
"Porquanto ela não consegue ser uma alternativa conseqüente ante a catarse do divertimento oferecidos em massa pela TV, pelo jornal, pelo rádio, pelo cinema padronizado, pelos teatros musicais. Nestes, o público contemporâneo satisfaz sua vontade de informação (rudimentar e parcelada), seu gosto de aventuras (sem que necessite sair da própria sala), de suspense, de violência a um preço baixo e cômodo"25.

Assim, o artista se vê recuado ante a comunicação de massas. Estamos vivendo um tempo em que a literatura, sendo autoconsciente, está voltada sobre si mesma. Ela tão somente consegue expressar a própria crise, a crise de seus autores ante a criação. A par desse recuo, as várias facetas através das quais se apresenta a comunicação de massa se apropriam das formas que anteriormente estavam apenas nas esferas artísticas.

Dessa maneira, os produtos da comunicação de massa, são oferecidos para um público cada vez mais reticente, cada vez mais cioso de se transformar em presa fácil do consumo, sob belas e envolventes embalagens. Valendo-se dos recursos do cinema, do teatro e da literatura, a comunicação de massa cada vez mais toma de empréstimo os elementos artísticos.

A linguagem literária e a linguagem da comunicação de massa têm, pois, suas configurações específicas e são reguladas por leis próprias, na medida em que têm objetivos diferentes. Enquanto aquela faz o registro do poético e que por isso transcende a objetividade, esta nunca sai dos domínios da pura objetividade da língua buscando uma comunicação imediata, com efeitos relâmpagos e que não deixam rastro na construção do imaginário. O desenvolvimento da comunicação de massa se dá horizontalmente, não pressupondo qualquer tipo de profundidade. Enquanto isso, num escopo diametralmente oposto, a linguagem literária se dá no plano vertical num processo que busca o efeito de conscientização no receptor, ao mesmo tempo em que empreende um mergulho na linguagem, cada vez mais rebuscada, problematizando a representação do real, ao mesmo em que empreende uma crescente elaboração da linguagem.

\footnotetext{
${ }^{25}$ Idem: 36.
} 
1. Sistema semiótico transparente (dá margem a vários enfoques);

2. Percurso da hermenêutica (parte do explícito para atingir a totalidade do sentido, o originário);

3. Não tem o objetivo específico de comunicar;

4. Leitura do espaço da representação;

5. Literariedade; Ruptura do sistema lingüístico (extrapolação do que é detectável simplesmente no nível do explícito);

6. Leitura no nível poético (sentidos possíveis sugeridos pela cadeia figurativa e fônico-expressiva);

7. Conclui-se no silêncio da linguagem (o texto literário só se consumará se for capaz de provocar o leitor para o desvelamento do que ele encobriu);

8. Atemporalidade, permanência, universalidade;

1. Infinitude de sentido, sintaxe luminosa, autônoma (plurissignificação);

1. Manifestação de si mesmo, autocriador;

1. Vigor da ausência, possibilitando maior ambigüidade;

2. Atitude criadora do autor;

3. Libertação do real empírico. Produtividade, evidenciando-se a qualidade.

4. Compromisso com a verossimilhança.
1. Sistema semiótico opaco (obscurecimento de vários sentidos em favor de apenas um);

2. Faz o percurso da modelização lingüística (limita-se ao lingüístico);

3. Tem o objetivo específico de comunicar;

4. Leitura no nível da representação;

5. Linearidade;

1. Leitura no nível do lingüístico (limitação ao que o signo expressa);

1. Atitude criadora atenuada, visando mais à reprodução do que à criação, produção;

1. Temporalidade, a produção respeita o gosto da época (moda), curta duração;

1. Fecha-se na estrutura da língua (a leitura do texto da comunicação de massa se realiza quando esgota o que foi expresso no nível do explícito).

2. Sintaxe iluminada, dependente (prédeterminismo na comunicação);

3. Vigor da presença, possibilitando menor ambigüidade, ou quase nula;

4. Finalidade prática de veículo de comunicação;

5. Sujeição ao real empírico;

1. Produção, evidenciando-se a quantidade. 
Mas as artes, e também a arte literária, obtiveram vantagens com o advento da indústria cultural. Com a possibilidade reprodutividade técnica dos produtos da arte, fato que ocorreu para atender ao gosto das massas composta pela crescente classe média, os meios de reprodução e difusão pelos via mídia impressa e eletrônica mostrou a que veio. Inestimáveis serviços foram então prestados à causa da popularização dos produtos das artes.

"A época da comunicação, em que vivemos, permite uma divulgação da obra de arte sem precedentes na história, colocando-a ao alcance qualquer um. A reprodutividade técnica, através dos mais diversos meios de multiplicação, tendendo a reduzir o valor material da obra de arte, significa também um distanciamento entre o produto original do artista, único e autêntico, e o seu espectador. A multiplicação representa, pois, um fator de mediação que implica, de um lado, acessibilidade à obra de arte, e de outro lado, perda do contato direto com o prejuízo do impacto emocional que ela pode transmitir" 26 .

A par dessa importante contribuição para a difusão dos produtos das artes, vemos que efeitos negativos também são produzidos. Basta atentarmos para o fato de que a nossa herança humanista, o legado que nos caracteriza enquanto construtores de toda uma cultura, acaba por ser obnubilado pelo processo de massificação. Assim, a nossa condição humana acaba sendo substituída indústria cultural traz como efeito perverso a padronização que a tudo iguala num só plano para atender a interesses econômicos.

Não custa enfatizar que essa massificação traz como indesejável conseqüência um espantoso empobrecimento estético. Tornam-se os homens objetos de sua própria civilização, a civilização da técnica que a tudo iguala a tudo desindividualizando, a tudo coisificando, provocando coletivamente uma irracionalidade. Eis aí os índices do nosso humanismo em derrisão. A palavra mecânica, audiovisualizada ocupa o lugar da palavra falada, a palavra que expressava a individualidade, a marca diferenciada pela qual cada ser se distinguia. A palavra e a imagem eletrônica ocupam com destaque as cenas do teatro das ações humanas.

As palavras e as imagens difundem-se em cada rincão ocupando todos os espaços sem ao menos pedir licença. Essas são as representações do poder absoluto que se instaura sibilinamente entre os homens encantados

$\overline{{ }^{26} \text { BRILL, Alice, } 1988, \text { p. } 61 .}$ 
com a técnica, hipnotizados pelas sucessivas imagens que não mais dão espaço para o pensar. Esvaziada de conteúdo, a palavra passar se configurar como símbolo sem significação. "Isso leva à isso leva à constatação paradoxal que a palavra, privada de sua força vital ao ser separada daquilo que designa, reveste-se de uma nova força mágica, no momento em que passa a ser símbolo de coletividade"27.

Com os meios eletrônicos de reprodução e difusão dos produtos das artes, sobrevém uma severa e dissimulada manipulação da arte. Como não poderia deixar de ser, as conseqüências passam pela perda, pelo esvaziamento ou impotência da ação individual.

Com Walter Benjamin constatamos a perda da aura da obra de arte. A transformação social ocorre concomitantemente (talvez uma influindo sobre a outra) com as mudanças verificadas no conceito estético. As técnicas de multiplicação inevitavelmente provocam a perda da aura da autenticidade da arte, que assim deixa de exercer função mítico-religiosa. Com isso, a tradição se vê esvaziada de sentido. Tudo é agora, tudo agora é instantâneo, imediato; tudo agora é passageiro, sem passado, sem as marcas da memória que nos dão o sentido da historicidade.

Contra as posições dos notáveis da Escola de Frankfurt, tão bem representados por Adorno e Benjamin, que investem com toda força contra a reprodutividade técnica e da qual adveio a indústria cultural, temos a visão relativizadora de Umberto Eco, em sua obra Apocalípticos e integrados. Eco faz uma percuciente análise na qual contesta o conceito de 'cultura de massa ' como sendo "genérico, ambíguo e impróprio". Para ele, a cultura de massa será uma anticultura se considerarmos a arte como expressão de uma interioridade que se opõe à vulgaridade da multidão. Dada a presença das massas humanas, a cultura de massa apresentaria índices apocalípticos não de limitações desintegradoras, mas indicativos integradores que reúne fatores positivos da cultura massificada.

Mas que índices positivos seriam esses? No mínimo, a inegável possibilidade de divulgação da cultura, a possibilidade de acesso por parte todos e uma tão sonhada derrubada de divisão de classes. Assim, os veículos democratizadores dos produtos da cultura como, o rádio, a televisão, o cinema, as revistas, os computadores possibilitam a ampla e irrestrita circulação de uma arte e de uma cultura popular.

\footnotetext{
${ }^{27}$ Idem, ibidem, 64 .
} 
Assim, para Umberto Eco, nada se afigura mais despropositado que o conceito-fetiche de "massa". Assim, esse desgastado conceito não se aplica apocalipticamente, tampouco integradoramente falando. Não cabe a nós criticar ou apoiar a massa. Não cabe a ninguém tentar protegê-la contra as explorações e as manipulações. Tal atitude denotaria, no mínimo, uma posição elitista. Nosso dever é, sim, o de reconhecer os direitos dessa massa em toda autonomia e plenitude. Contra os inevitáveis exploradores vestidos na pele de cordeiro dos operadores culturais, lembremos com Marx: "Se o homem é formado pelas circunstâncias, devemos tornar humanas estar circunstâncias". Se é através da fruição individual e solitária dos produtos da literatura e das artes que conseguimos nos humanizar, resta perguntarmos: não se processará também a humanização das massas, mesmo via os produtos da indústria cultural, na medida em que as circunstâncias vividas pelas massas também estejam humanizadas? Ao compartilharmos solidariamente os produtos da arte com a massa, de certa forma, não estaremos também compartilhando com as massas a nossa visão de mundo, as nossas emoções, a nossa humanidade?

\section{Referências Bibliográficas}

BAKHTIN, Mikhail. Estética da criação verbal. Trad. (a partir do francês): Maria Ermentina G. G. Pereira São Paulo: Martin Fontes, 2000.

BARTHES, Roland. [et. alii]. Trad. Raquel Silva. Escrever... Para quê? Para quem? Lisboa: Edições 70, 1975.

BRILL, Alice. Da arte e da linguagem. São Paulo: Ed. Perspectiva, 1988.

BURKE, Peter. A escola dos Annales (1929-1989): a revolução francesa da historiografia. Trad. Nilo Odália. São Paulo: Ed. UNESP, 1991.

(Org.). A escrita da história: Novas perspectivas. $2^{\mathrm{a}}$ ed. São Paulo: Ed. UNESP, 1992.

ECO, Umberto. Apocalípticos e integrados. São Paulo: Ed. Perspectiva, 1976.

FISH, Stanley. "Como reconhecer um poema ao vê-lo". In: Palavra. Revista do Depart ${ }^{\circ}$ de Letras da PUC-Rio. Rio de Janeiro: Depart ${ }^{\circ}$ de Letras, 1993.

JAKOBSON, Roman. Lingüística, poética e cinema. Trad. de Francisco Achcar [et alii]. São Paulo: Ed. Perspectiva, 1970. 
. Poética em ação. Seleção, prefácio e organização: João Alexandre Barbosa. São Paulo: Ed. Perspectiva, 1990.

JAUSS, Hans Robert. A história da literatura como provocação à teoria literária. Trad. Sérgio Tellaroli. Sã Paulo: Ed. Ática, 1994.

JOBIM, José Luís. Palavras da crítica: tendências e conceitos no estudo da literatura. (Org.). Rio de Janeiro: Imago Editora, 1992

A poética do fundamento: ensaios de teoria e história da literatura.

Niterói/RJ: EdUFF, 1996.

Formas da teoria: sentidos, conceitos políticas e campos de força nos estudos literários. Rio de Janeiro: Ed. Caetés, 2002.

LIMA, Luís Costa. Por que literatura. Petrópolis: Ed. Vozes, 1969.

. Controle do imaginário: razão e imitação nos tempos modernos. $2^{\text {a }}$

ed. revista e ampliada. Rio de Janeiro: Forense Universitária, 1989.

. A metamorfose do silêncio: análise do discurso literário. Rio de Janeiro: Livraria Eldorado Tijuca, 1984.

OLINTO. Heidrun Krieger. Histórias de literatura: as novas teorias alemãs. (Org.). São Paulo: Ed. Ática, 1996.

SILVA, Maria Beatriz Nizza da. (Organização, seleção de textos , tradução, e introdução). Teoria da história. São Paulo: Ed. Cultrix, 1986.

SCHMIDT, Siegfried J. Ciência da literatura empírica: uma alternativa. Trad. Apresentação: Heidrun Krieger Olinto. Rio de Janeiro: Ed. Tempo Brasileiro, 1989.

VEJA - edição 1439, de 10/04/96. 